\title{
أثر ستراتيجية سوم في ثدريس البنية الرياضية والتفكير الجانبي لدى طلاب الصف الاول المتوسط
}

م.د. مهمد مريد عراك

كلية التربية - جامعة القادسبة مبنة

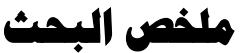

هدف البحث الى التعرف على اثر ستراتيجية سوم في تدريس البنية الرياضية و التفكير الجانبي لاى طلاب الصف الاول

المتوسط . استخدم الباحث التصميم التجريبي ذو الضبط الجزئي لمجموعتين متكافتتين ، اعد الباحث اختبارين الاول اختبار

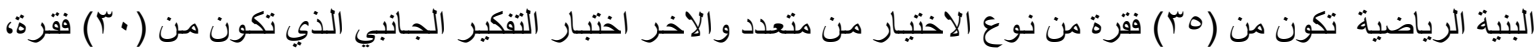

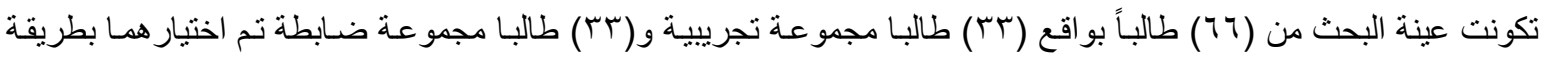
عشو ائية وتم مكافئتهما ببعض المتغيرات استخدم الباحث الاختبار التائي كوسيلة احصائية ، اسفرت النتائج عن تفوق طلاب المجموعة التجريبية الذين درسو اعلى وفق ستراتيجية سوم على طلاب المجموعة الضـابطة الذين درسوا على وفق الطريقة الاعتيادية في اختباري البنية الرياضية و التفكير الجانبي.

\section{Abstract}

The aims of current research to know the effect sowm strategy on mathematics structure and lateral thinking of first grade students average. The researcher using a design set equal part between two groups ( experimental and control ), the researcher developed tow tests, the first for mathematics structure of (35) items and the other for lateral thinking of (30) items. The sample consists of (66) students distributed into two groups, experimental consisted of (33) students, and control group consisted of (33) student, and equal groups of some variables, the searcher use t-test as a statical tool, the result showed that theirs difference of statistic significance at the level (0.05) between the average of the students of experimental group which study according sowm strategy and the control group which study in classical method in mathematics structure and lateral thinking.

\section{الفمل الاول- التعريف بالبمث \\ اولا:- مشكلة البحث}

مشكلة البحث الحسالي تتمثل في وجود اوجه قصور في الاسـاليب والستر اتيجيات المتبعة في تدريس

مادة الرياضيات، اذ اصبحت الرياضيات مجرد مـادة تعطى للطالب دون ان تتاح لـه امكانية فهم بنيـة المـادة الرياضية و التفكير في مـا تعلمـه. ويصسب أحيانـا التعبير عن كثير من المفاهيم العلميـة، من دون استخدام الرياضـيات وممـا تتضـمنه مـن (المفـاهيم، المهار ات، التعميمات،النمـاذج، ، · )، كمـا عدت الدول المتقدمـة

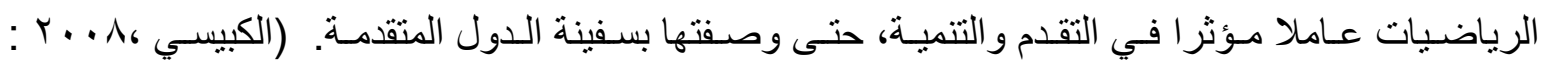

و هناك اعتقاد خاطئ لدى الطلاب بـأن الرياضيات مـادة غير ممتعة وصعبة التعلم وانه لا يمكن لكل الطلاب تعلمها، و انها مادة مجردة لا يشعر الطلاب بها أو بقيمتها في حياتهم، كما إنها مادة غير مشوقة وجافة تتطلب حفظ واستظهار الكثير من النظريـات والقوانين ـ وقد ذكر (الكتبي، 997 ()) انسه توجد العديد مـن الثوا اهد على النقص الثنديد في امتلاك الطلاب للمهار ات الأساسية مثل القدرة على إجراء العمليات الرياضية بيسر وطلاقة، والحس بسلامة النتائج التي تظهر عند اجر اء عمليات رياضية، و هنالك نقص في القدرة على إهى 
التفكير التحليلي عند حل المسائل و المشكلات الرياضية و هنـالك قصور شديد في حل مسـائل غير نمطية أو

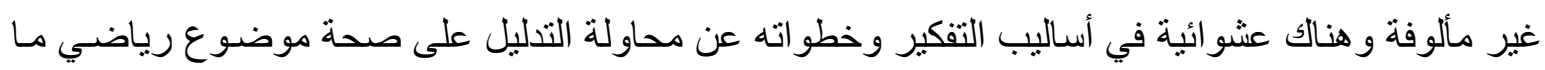

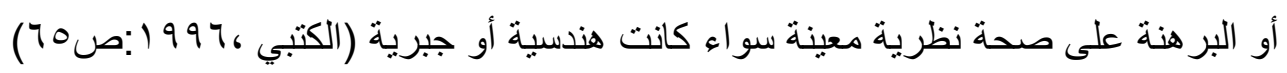

وتعد الرياضيات من المجـالات المعرفيـة المهمـة وذلك لإسـهاماتها الكبيرة ومشـاركتها في المجالات المعرفية الاخرى ، اذ لا يمكن للمجالات المعرفية الاخرى ان تتقدم دون الاعتمـاد على الرياضيات ـ ومن لهن

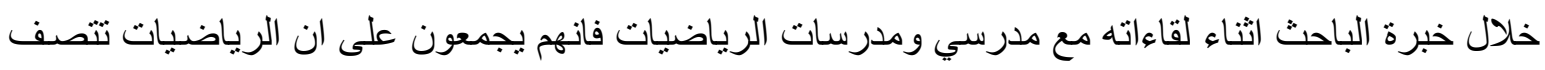
بالنفور و الكره و عدم التقبل من قبل الطلبة اذ يعانون من صسعوبة التفكير ببعض المسـئل ، كذللك ومن خـلال زيار ات الباحث للطلاب اثناء فترة التطبيق لاحظ ان الطلبة لا يبالون في عدم معقولية النتائج الحاصلين عليها من حل مسالة معينة، مثال على ذلك اذا ظهر الناتج عبارة عن كسر في مسالة مطلوب فيها عدد موظفين او يظهر زمن معين بالسالب، وهذا ناتج من ضعف في التفكير وقد يكون هذا الضعف نـاتج من ذات الطلبة او ستر اتيجيات تقديم المادة وليس العيب في المادة نفسها.

لذلك كـان من الأفضل إتبـاع ستر اتيجيات تـدريس حديثة في تدريس مـادة الرياضيات للتغلب على القصور في الأساليب التقليدية المتبعة عسى أن تؤدي الى زيـادة تحصيل الطلاب فيها وتتوع اسـاليب التفكير

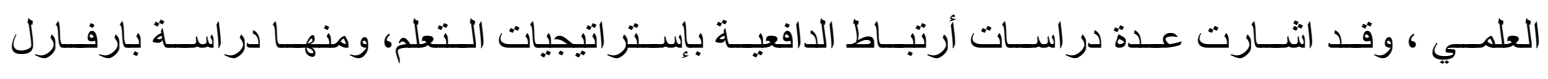

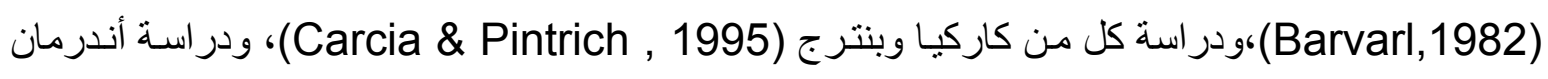
ويونك (Anderman\& Young, 1994) التي وجدت إن تدريس الطلاب مجموعـة مـن إستر اتيجيات

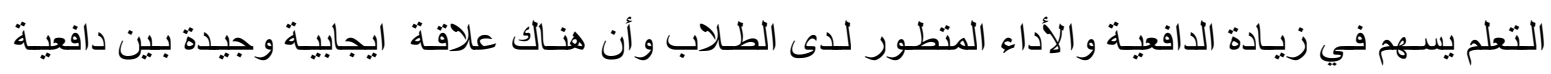

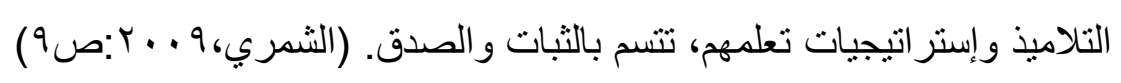

لذا فقد صاغ الباحث مشكلة بحثه بالتساؤل (ما أثر ستر اتيجية سوم في تدريس البنية الرياضية و التفكير

$$
\text { الجانبي لدى طلاب الصف الاول المتوسط في مادة الرياضيات)؟ }
$$

ثانيا:- اهمية البحث: - مئ

من الامور التي دفعت الانسان للبحث والتقصي عن افكار جديدة واسـاليب وستر اتيجيات مؤثرة فادرة على مواجهة متطلبات العصر وتحدياته ، هو ما يثهده القرن الحادي والعشرين من ثورة علميـة وتكنولوجيـة كبيرة كان لها الاثر الواضح في جو انب الحياة المختلفة، اضافة الى ضرورة الافادة من التطور ات التقنية التي

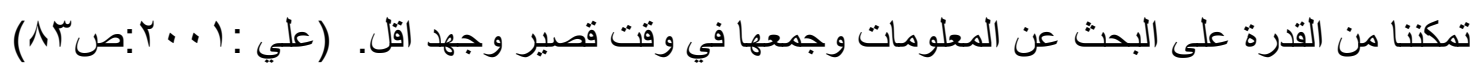
وتعد التربية عملية انماء شاملة تهذف الى الانتقال بالفرد من و اقعه الحالي الى مستوى عال من الرقي

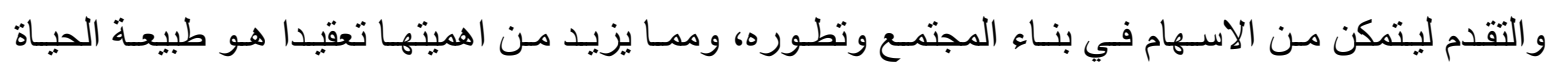

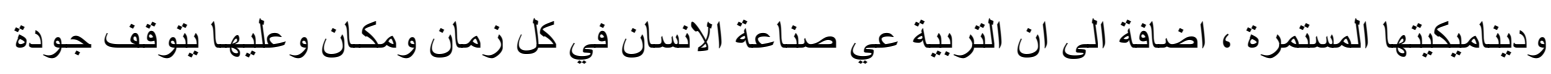
بنيانه وبها يتحسن كيانه، فاذا احسنت الصناعة حسن المنتوج ، ومن خلالها يتعلم الانسـان الابداع في الحياة

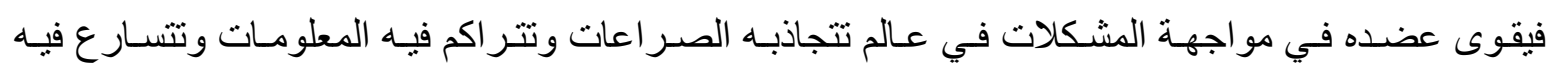

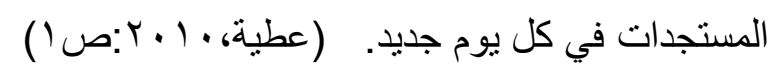


و على الرغم من الجهود الكبيرة التي بذلتها المؤسسـات التعليمية ،ومـا طر أ عليها من تحولات كميـة وكيفية، الا ان بر امجها و انشطتها واساليب تدريسها لاز الت تركز على التلقين للحقائق و المعلومات، ولا زال دور المتعلم سلبيا في العملية التعليمية يقتصر على تلقي المادة الدر اسية الموجودة في الكتب المنهجيـة المقررة و واستظهار مـا يطرح عليه دون نقد او بحث، وهذه الحالة تنطبق على واقع التعليم في كافة مر احله وحتى التعليم الجـامعي الذي من المقترض ان ينمسي المنهج العلمي في تفكير الطلبـة على وفق متطلبـات العصـر

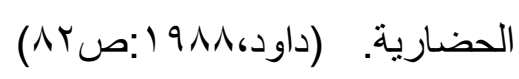

وتعد طريقـة التـدريس اداة مـن خلالهـا يمكن نقل العلم و المعرفـة الـى المتعلم ، ولذلك فـان الاهداف

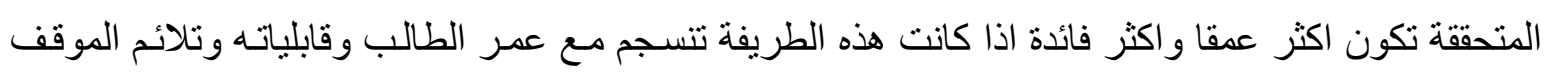
التعليمي ، ولا توجد طريقة مثلى لتدريس جميع المواد الدراسية بل لكل موقف تعليمي هناك طريقة تناسبه.

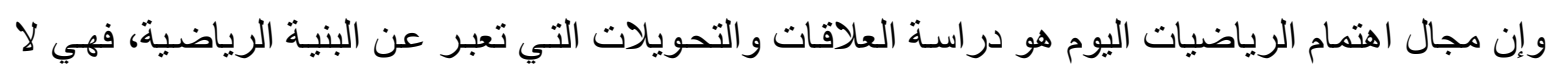
تدرس المكونات الرياضية (حقائق، مفاهيم، تعميمات، .....) فحسب و إنما تدرس العلاقات بين تلك المكونـات

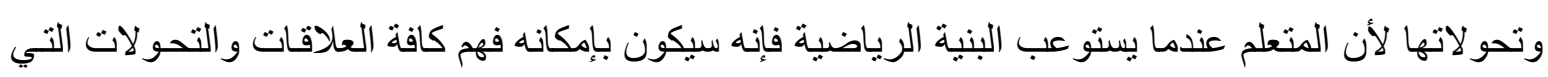

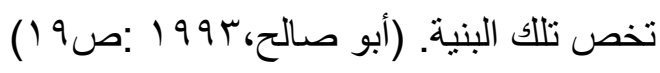
و ان الرياضيات مجموعـة من الأنظمـة الرياضية ، و النظـام الرياضـي عبارة عن بنـاء استنتاجي يقوم

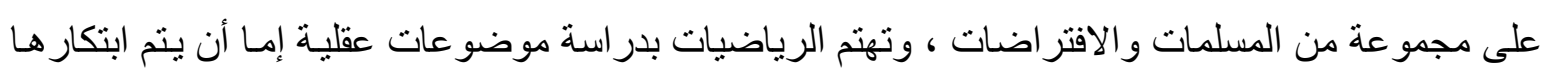

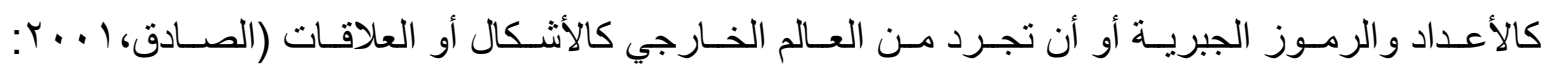
صب ا ()، ومعرفة بنية الموضوع و أساسياته هو وسيلة لتحقيق هدف انتقال المعرفة والتدريب إلى مو اقف ونف

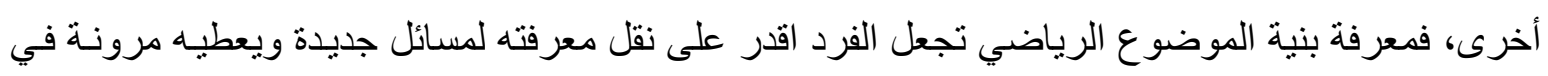
معالجة المسـائل الرياضية المختلفة وتحليل المواقف الجديدة، كمـا يدخل عددا من المو اقف كحساتلات خاصـة للحالة العامة التي تعلمها مما يوسـع مجال التعلم لديـة وان مـا يميز المشـاريع الحديثة لمنـاهج الرياضيات هو

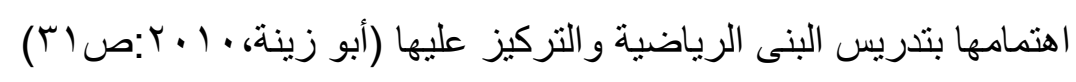
وتعد الستراتيجيات التي يتبعها المدرس من اهم الجوانب العملية التعليميـة بل هي المحور الرئيس في

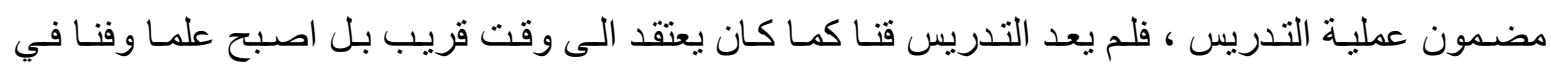
ان واحد (Goet Z.E,1992:p109) وفي السنوات الاخيرة ظهرت ستر اتيجيات نقلت العملية التعليمية من المـادة الدراسية والاعتمـاد على المدرس الـى الاهتمـام بالطالب باعتبـاره محسور العمليـة التعليميـة ومركزا

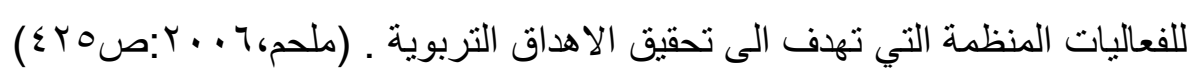
ومن هذه الستراتيجيات ستراتيجية (سوم) التي تعد احدى ستراتيجيات التفكير العليا التي تستند الى دمج مهار ات التفكير بـالمحتوى الدر اسي ، ويؤكد منظرو هذا الاتجاه و على راسهم (روبرت سوارتز)، ان تعلم التفكير عن طريق المواد الدراسية، يعزز تعلم العمليات العقليـة، بحيث يدرك الطالب ان الربط مفيدا بين مهرات التفكير ومجالات تطبيقها في مختلف النشاطات اليومية ، وان الهدف من وراء هذه الجهود هو العمل ئل 
على تحسين التعلم ونتاجاتـه لمو اكبة مستجدات عمليتي التعلم و التعليم وتحسين مهار ات الطلاب في التفكير

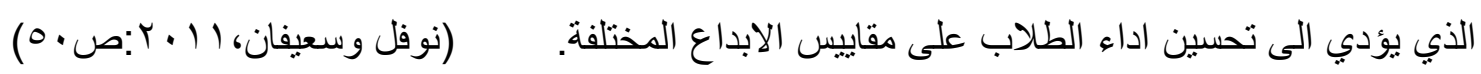
ويعد التفكير الجانبي احد انماط التفكير الحديثة والذي يرى العـالم (ادوارد دي بونو) بانـه اتجاهـا جديدا

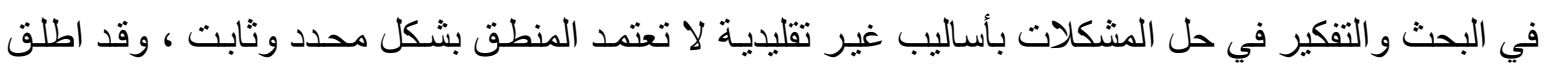

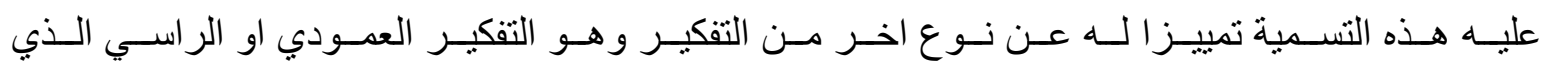
يعتمد بالأساس على التفكير المنطقي بين المقدمات والنتائج، وهذا النوع من التفكير هو الثـائع والمـألوف بين

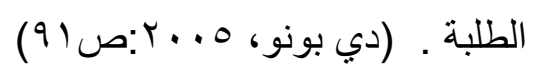
لذا تكمن اهمية البحث الحالي في: - 20 - n

ا ـ عدم وجود در اسة على حد علم الباحث تناولت اثر ستر اتيجية سوم في البنية الرياضية . r- اهمية ستر اتيجية سوم في مساهتها بتحويل دور الطالب من متلقي الى مفكر فعال داخل الصف. rـ امكانية استفادة الجهات المعنية من نتائج البحث في تطوير وتدريب الملاكات التدريسية. ع- اهمية التفكير الجانبي باعتباره نمط من انماط التفكير الابداعي. ثالثا: اهداف البحث: بهدف البحث الحسالي الى تعرف ( اثر ستر اتيجية سوم في تدريس البنية الرياضية و التفكير الجانبي لدى طلاب الصف الاول المنتسط ) ). رابعا- فرضيات البحث: من أجل تحقيق أهداف البحث، صيغت الفرضيتان الصفريتان الآتيتان: ا ـ لا يوجد فرق ذو دلالـة إحصـائية عند مسـتوى الدلالـة (0 . . • ) بين منوسط درجـات طـلاب المجموعـة التجريبية التي درست على وفق ستر اتيجية سوم ومتوسط درجات طلاب المجموعة الضـابطة التي درست بالطريقة التقليدية في اختبار البنى الرياضية. r. لا يوجد فرق ذو دلالـة إحصـائية عند مسـتوى الدلالـة (0 . . • ) بين منوسط درجـات طـلاب المجموعـة التجريبية التي درست على وفق ستر اتيجية سوم ومتوسط درجات طلاب المجموعة الضـابطة التي درست بالطريقة التقليدية في اختبار التفكير الجانبي. خامسا- حدود البحث: يقتصر البحث الحالي على: ا ـ طلاب الصف الاول المتوسط في المدارس المتوسطة والثانوية التابعة الى مديرية تربية القادسية.

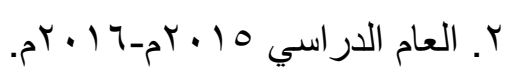
r. موضو عات الفصـول (المجموعـات ،العلاقات، الاعداد الصحيحة ) من كتاب الرياضيات للصف الاول

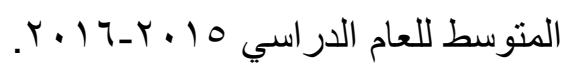
سادسا- تحديا المصطلحات:

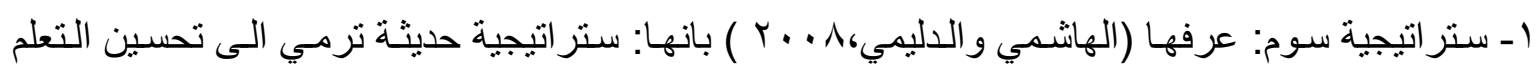

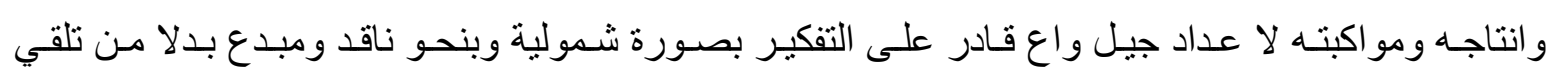


المعلومة دون التفاعل معها وكيفية حلها ومن مميز اتها السـهولة والدقة في التفاصيل بمجموعة افكار و اسئلة

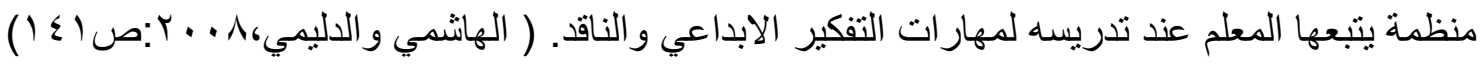
ويعرفها الباحث اجر ائيا بانها: مجموعة من الاجراءات والخطوات المنسقة والمنتظمـة يتبعها المدرس في تدريسـه المجموعـة التجريبيـة لمسادة الرياضيات للصف الاول المتوسط بهدف الوصسول الى اكبر قدر ممكن من الافكار و المعلومات في الموقف التعليمي المحدد. ץ- البنية الرياضية: عرفها (أبو زينـة، بر9 (1) بأنها : مجموعة من العناصر و على هذه المجموعة نضع هيكل أي مجموعـة مـن القو اعد و العلاقـات تحدد طرق العمل و هذه القو اعد تقودنـا الـى دراسـة الخصـائص

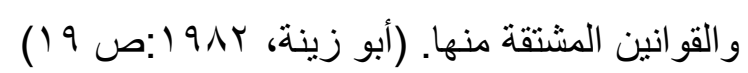
و عرفها (الكتبي، 991 () بأنها : عبارة عن ثلاثي من مجموعـة أساسية ومجموعـة علاقات عليها

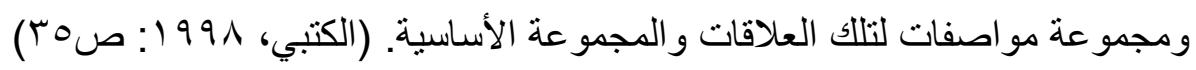
ويعرفهـ الباحث اجر ائيـا بآتـه: بأنها مجموعـة العناصـر و المكونـات الرياضية مـن حقائق ومسـلمات و وفاهيم ومهار ات وتعميمات والعلاقات الرياضية على تلك العناصر و المكونـات، التي يظهر الطالب اتقانها من خلال الدرجة الكلية التي يحصل عليها في الاختبار المعد لذلك .

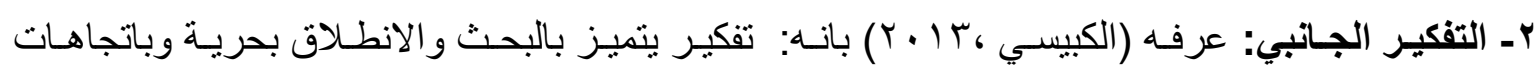

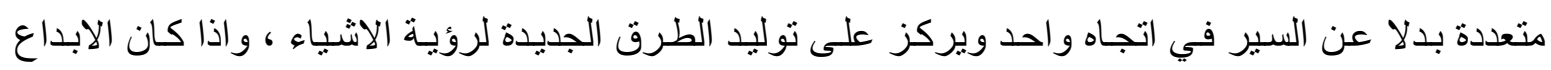
طريقة استخدام عقولنا فان التفكير الجانبي خير وسيلة لاستخدام عقولنا فهو اداة الابداع ومن الممكن تتمية

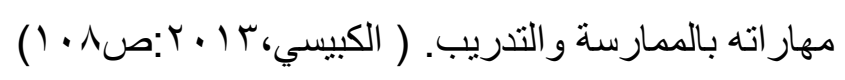
ويعرفه ( عرفة، ج ج . ب) بانه: نمط من التفكير يعتمد على ابتكار اكبر عدد ممكن من الحلول والبدائل ويمكن النظر من خلاله على اكثر من جهة في المشكلة او المواقف والقفز بخطوات حل المشكلة . (عرفة،

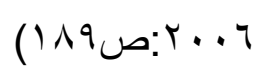

ويعرفه الباحث اجر ائيا بانه: نمط من التفكير الذي يقاس من خلال الدرجة التي يحصل عليها الطالب في اختبار التفكير الجانبي المطبق في البحث الحالي.

\section{الفمل الثاني- اطار نظري ودراسات سابقة}

اولا:- اطار نظري

ستراتيجية سوم: ان تسمية سوم (SWOM) جاءت لتعبر عن منظومـة تعليمية اطلق عليها اسم الانموذج الامثل الواسع او الثنامل لكل مدرسة ، اختصر بكلمة (SWOM) وذللك باعتماد اول حرف من كل كلمـة من اسم الستر اتيجية باللغـة الانكليزيـة (School Wide Optimum Model ) وقد شـارك في ذلك مدير المركز الوطني لتعليم التفكير في بوسطن في الولايـات المتحدة الامريكيـة البروفيسور روبـرت سـوارتز

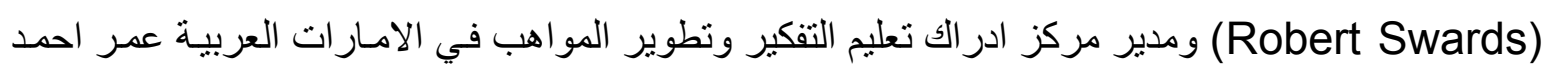
(Omar Ahmed) ، واسم الستر اتيجية يتكون كذلك من شقين، الثـق الاول (SW) وهمـا الحرفـان الاولان 
من (Swards) و الثـق الثاني (OM) و همـا الحرفـان الاو لان من (Omar) لأنهـا تقدم برنامجـا تطويريـا

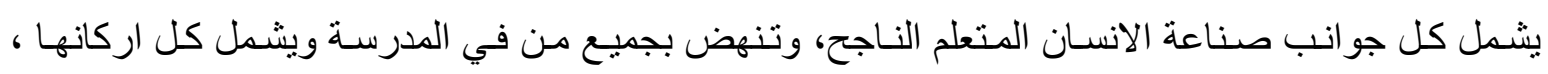

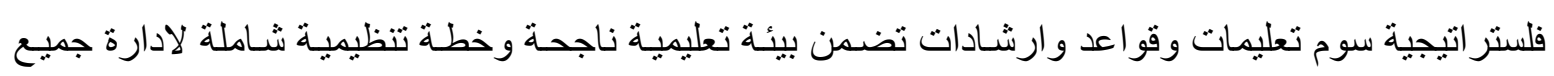
اجز ائها التي تتظم المدرسة باسر ها ، فهي شاملة بكل ما تحتويه وشاملة لكل افراد المدرسة . ان ابرز ما يميز هذه الستر اتيجية هو سهولة التعامل معها اذ تتسم بالوضوح و الدقة في التفاصيل ، وهي تمثنل مجموعـة من

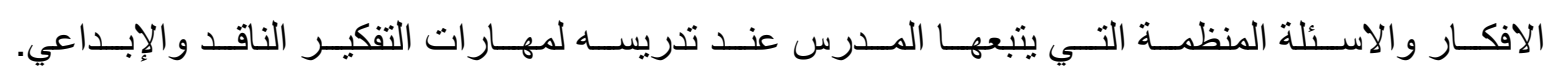

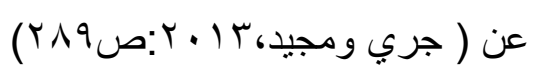

مهارات ستراتيجية سوم (swom): تتكون ستر اتيجية سوم من ست مهار ات للتفكير هي: ا - مهارة التساؤل: تستتد هذه المهارة الى طرح الاسئلة قبل واثناء وبعد عملية التعلم، بمـا يسير فهم الطالب

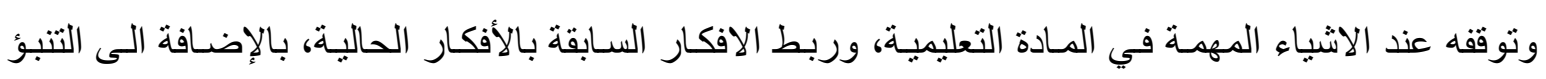

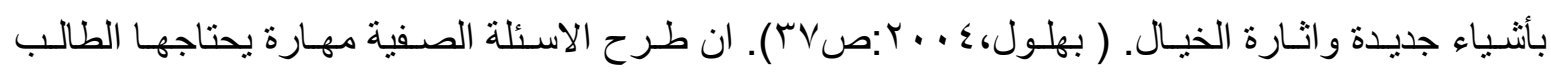

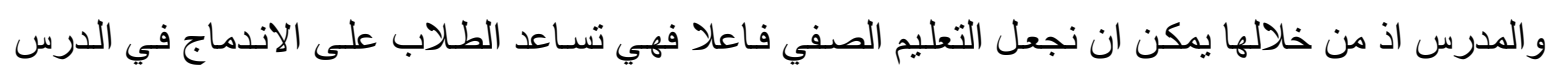
بنشاط لا نها تجعل الطالب فاعلا في الموقف التعليمي بدلا من ان يكون متلق ودوره سلبي، اضـافة الى ان

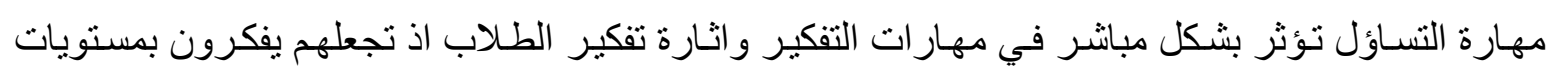

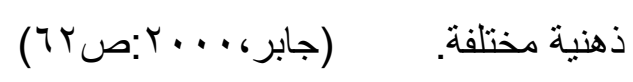
ז- مهارة المقارنة: تتضمن مهارة المقارنة تحديد اوجه التشابه والاختلاف بين فكرتين او حادثتين اذ تحتوي على الخصائص المتشابهة والخصائص المختلفة ، و هي من مهار ات التفكير الاساسية والتي تهدف الى تنظيم

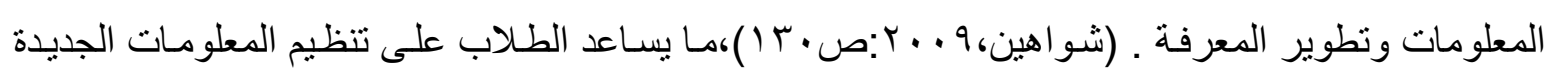
و المعلومات المخزونة بطريقة بسهل استرجاعها وتضم مجموعة من العمليات المعرفية وهي الدقة و التمبيز

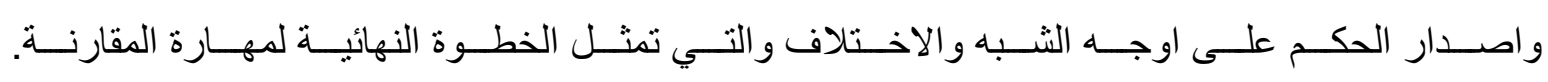

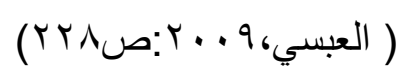

بـ مهارة توليد الاحتمالات: تتضمن هذه المهارة استخدام المعرفة السـابقة لإضـافة معلومات جديدة بصورة

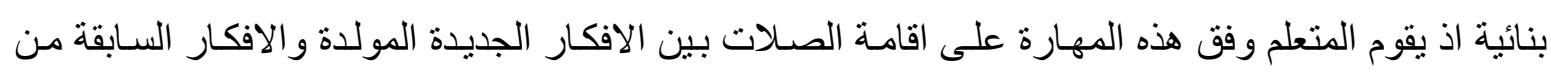

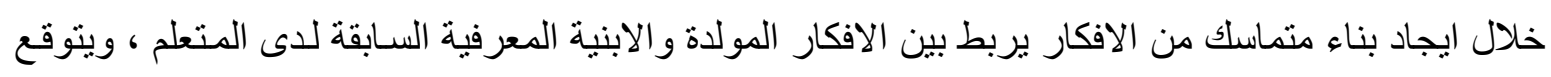

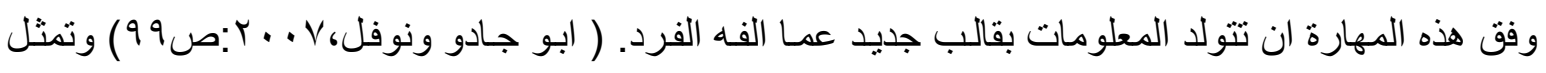
قدرة الطلاب على توليد اكبر قدر ممكن ن الحلول المألوفة وغير المألوفة للمشكلات او الو اقف التي تجابههم

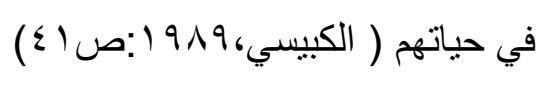

ع - مهارة التنبو: مهارة التنبؤ تستخدم من قبل شخص معين يفكر فيما يحدث في المستقبل، وبالنسبة للطلبة

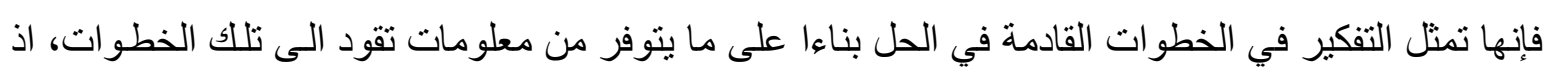

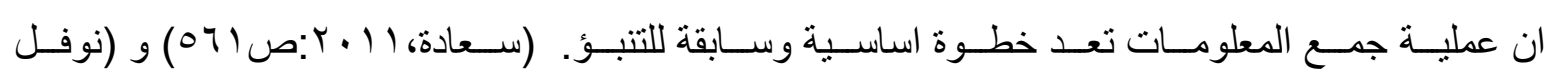

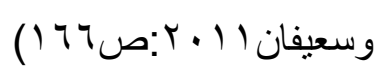


ويمثل التنبؤ مهارة في قراعة البيانات والمعلومات المتو افرة والاستدلال عن طريقها الى ما هو ابعد من

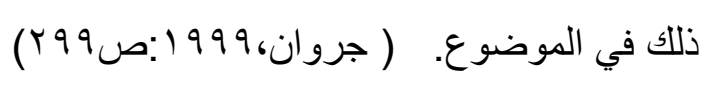

هـ مهارة حل المشكلات: تستخدم للتحليل ووضـع ستر اتيجيات تهدف الى جل سؤال صسب او موقف معقد

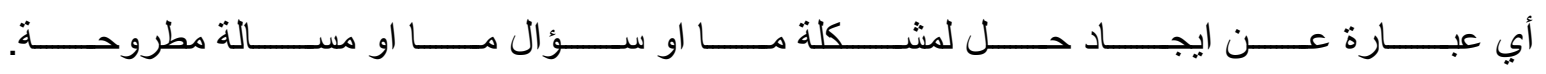

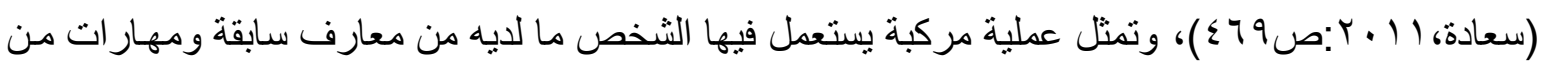

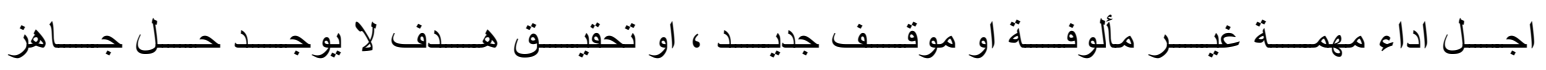

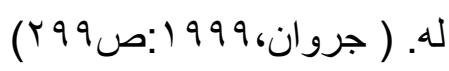
7- مهارة اتخاذ القرار: تتبلور عملية اتخاذ القرار في ثلاث عمليات فرعية وهي البحث و المفاضلة والمقارنـة بين البدائل واختيار افضل هذه البدائل، ويرى البعض ان القرار عمليـة ذهنيـة عقلية بالدرجة الاولى، تتطلب

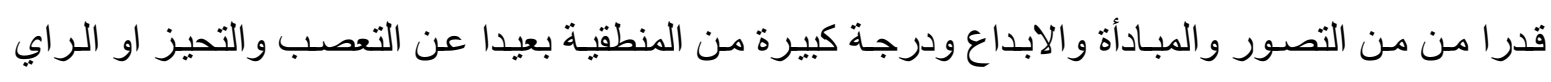

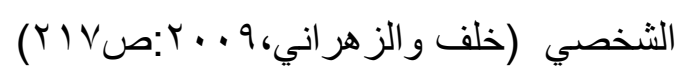

وتمثل عملية تفكير تهدف الى اختيار افضل الحلول المكنة للفرد في موقف معين من اجل الوصول

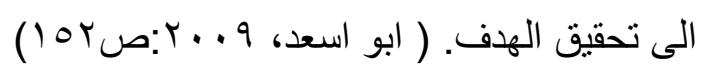

البنيـة الرياضـية: ذكر (الحسني ،91911) عدم وجود اتفـاق شـامل ومحدد ومقبول حول تحديد مصطلح

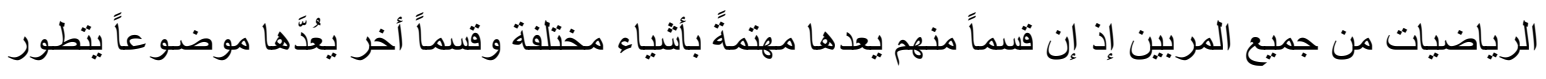
مع مرور الزمن ـ وقسماً ثالث يعرفها بأنها در اسة الهندسة والحساب بينما يحددها الفيلسوف (برتز اند ) بأنها ذللك الموضـوع الذي نتحدث من خلالها عن أثـياء لا نعرفها و لا نعـرف أن كـان حديثنا صـحيحاً أو غير

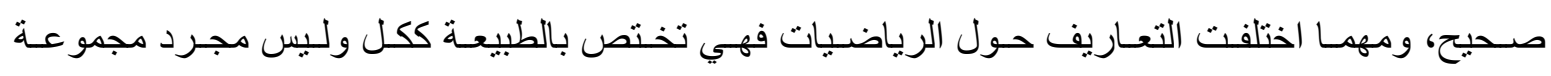
التطبيقات في العلوم الأخرى لذلك تعد الرياضيات حلقة وصل بين الرياضيات التطبيقية و العلوم الأخرى من

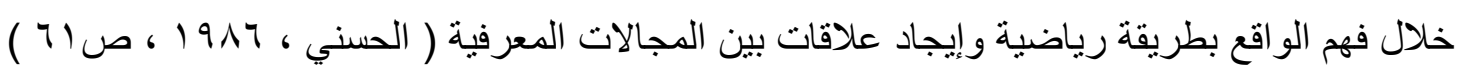
وقد أصبحت در اسـة الرياضيات تقوم على مفهوم المجموعـة والهيكل (البنيـة) أي مجموعـة مـن

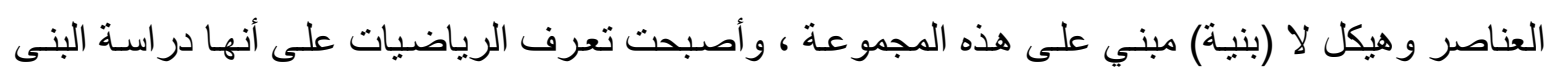
و العلاقات بين هذه البنى (Dienes , 1977 , P229)

و الفكرة القائلة بأن للمادة الرياضية بنية وان فهم هذه البنية ينبغي أن يكون الهدف الرئيس في التدريس

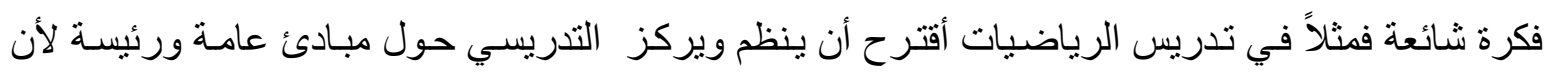

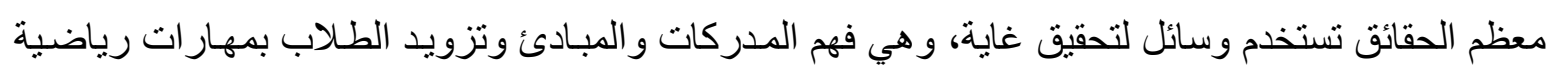
ضـرورية لهم ومـن هنـا ومنذ عدة سنوات بـأ علمـاء الرياضيات يفحصـون بنيـة مـادتهم ليتعرفوا المبادئ

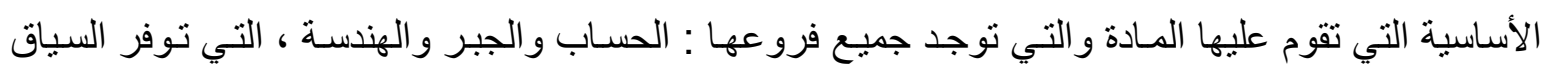

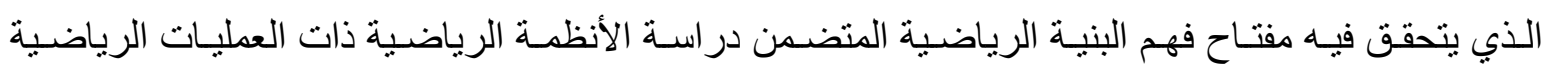


ووصفت الرياضيات بأنها در اسة أنظمة رياضية المتكونة من بعض العناصر الرياضية المجردة التي تربطها

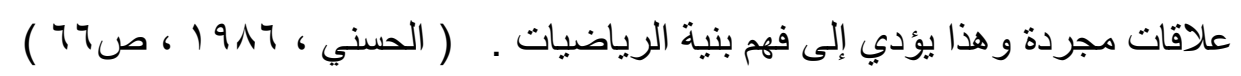
ان البنية الرياضية هي ثلاثي مرتب يتكون من مجموعة غير خالية ، و علاقات على هذه مجموعة، و ومسلمات (سمات) أو وصف لتلك العلاقات على المجمو عة، بمعنى انها منظومة من العناصر و العلاقات التي هي هني تحكـم التعامـل بهـذه العناصـر وقـــ تتضــمن معرفـات (تعـاريف) و لا معرفـات ومســلمات ومبر هنــات

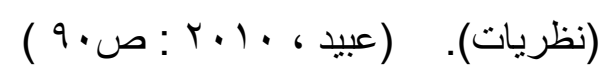

وبصورة عامة يمكن تمثيل بنية مادة الرياضيات في المستويات التي يتضمنها الثكل الهرمي الآتي :

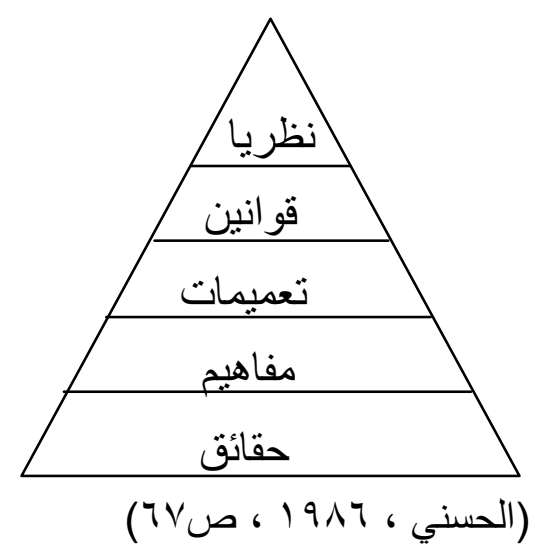

إْذ مثنل الثـكل في أعـلاه المكونـات الرياضـية لكل بنيـة مـن البنـى الرياضـية الثناث، ومسن هنـا فـإن

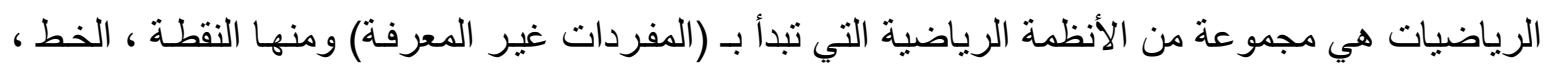

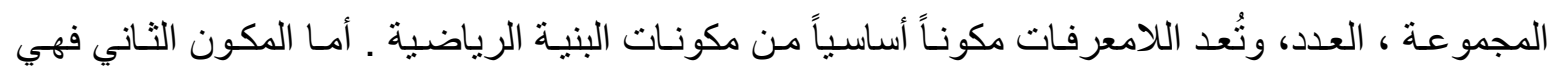
(التعريفات) و التعريف هو وصف .... اللفظ أو المصطلح أو الثـيء وتحديد مفهومـه و تقوم هذه التعريفات على المفردات المعرفة وغير المعرفة لتصف الصفات الأساسية للفكرة أو المفهوم أو الرمز بوضـع الاهتمسام

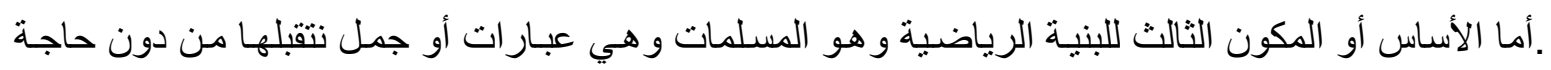

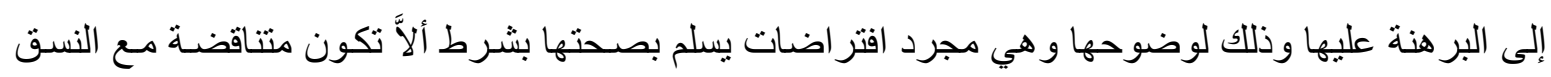
الرياضي فلا تتناقض مـع التعريفات مثنلاً . أمسا الأسـاس أو المكون الرابع من مكونـات البنيـة الرياضية فهو

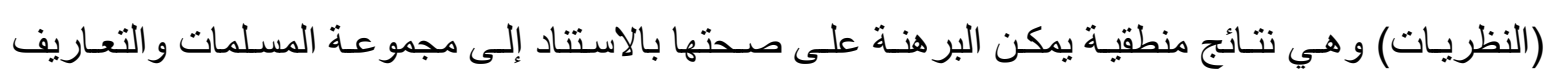

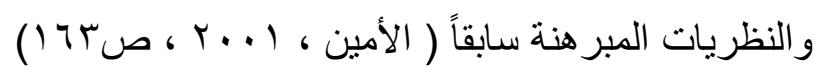

التفكير الجـانبي: يعود هذا النمط من التفكير الى المفكر ادوارد دي بونو (Edward De Bono)وهو طبيب بريطاني انتقل في تخصصه من الطب البشري الى الفلسفة واستعمل معلوماته الطبية عن المـخ واقسامه و عمله في تحليل انمـاط من تفكير النـاس واصبح اثـهر اسم في العـالم في مجـال التفكير وتحليله و انماطه و اقترح عدة نظريات في هذا المجال ومن اثـهرها ( التفكير الجانبي والقبعات الستة والكورت).ويعد التفكير الجانبي بمثابة نمط من التفكير يعتمد على ابتكار اكبر عدد ممكن من الحلول و البدائل ، ويمكن من خـلال التفكير الجانبي النظر الى اكثر من جهة في المشكلة او الموقف والققز بخطوات حل المشكلة أي الابقاء على هلى 
كــل المعلومــات المتاحسـة ، ويركــز التفكيــر الجـانبي علــى واقــع الامــر ولــيس الامــر الواقــع .

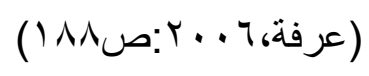

مهارات التفكير الجانبي

ا ـ توليد ادراكات جليدة: المقصود بـالإدر اك هو الفهم ، بمعنى ان يصبح المتعلم قادرا على ادراك الاشياء

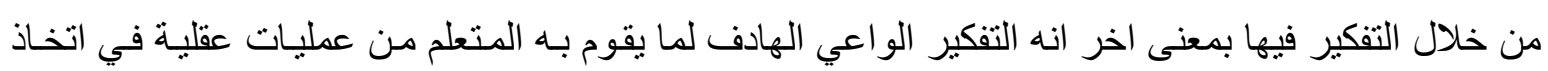

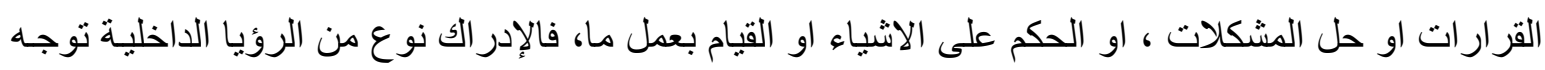
المتعلم نحو الفكرة بهدف فهمها.

r- توليد مفاهيم جليدة: يثير دي بونو الى ان المفاهيم هي اساليب او طرق عامـة لعمل الاشياء ويعبر عن المفاهيم احيانا بطرق واضحة ولكي نعبر عن مفهوم ما ، لابد من بذل مجهود لاستخلاص هذا المفهوم. r- توليد افكار جديدة : يؤكد دي بونو ان الفكرة شيء يتصور من خلال العقل و الافكار هي طرق ماديـة لتطبيق المفاهيم والفكرة يجب ان تكون محددة وتوضع موضع الممارسة. عـ توليد بدائل جديدة : التفكير الجانبي هو طريقة خاصـة لتأمل الحلول بين مجموعـة ممكنة او متاحسة، اذ

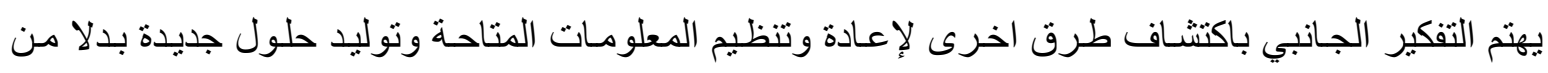

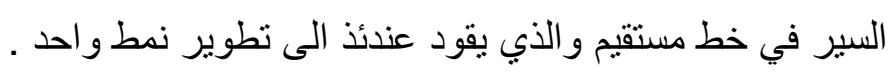
هـ توليد ابداعات جليدة: يؤكد دي بونو ان الابداع هو العمل على انشـاء شيء جديد بدلا من تحليل حدث

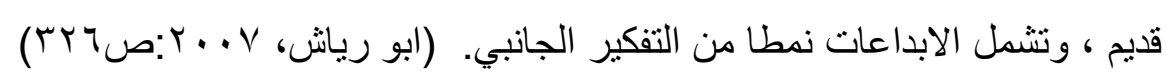

ثانيا: دراسات سابقة ا ـ دراسات تتعلق بستراتيجية سوم: ـ در اسة المرسومي (11 (1)): اجريت الدر اسة في العر اق و هدفت الى التعرف على اثر ستر اتيجية سوم في

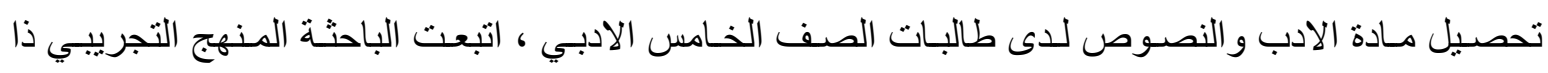

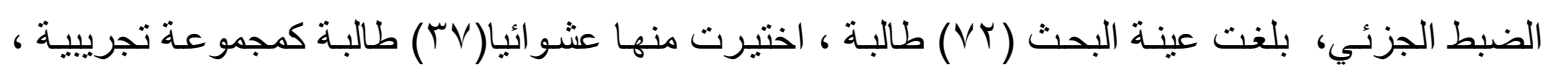

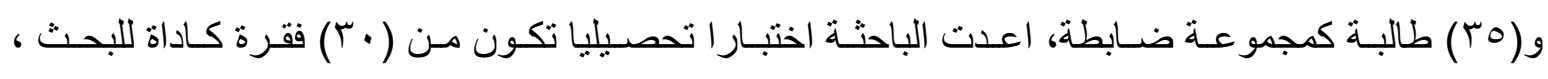
استخدمت الباحثة الاختبار التائي كوسيلة احصـائية ، اسفرت النتائج عن تفوق طالبـات المجموعـة التجريبية اللائي درسن على وفق ستر اتيجية سوم على طالبات المجموعة الضـابطة اللائي درسن على وفق الطريقة الاعتيادية. ( المرسومي ، (1)

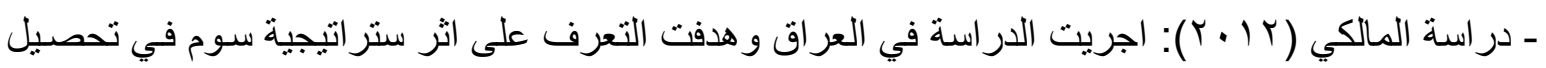
قو اعد اللغة العربية و الاحتفاظ لدى طلاب الصف الخامس الادبي ، بلغت عينة البحث (7 آج) طالب، اختيرت

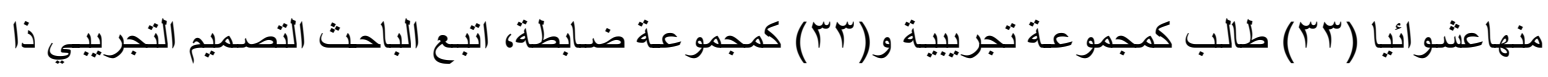
الضبط الجزئي، اعد الباحث اختبار ا تحصيليا تكون من (•r) فقرة من نوع التكميل والاختيار من متعدد

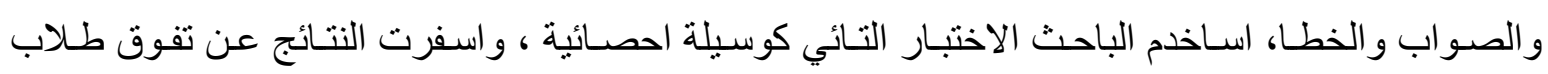


المجموعة التجريبية اللذين درسوا على وفق ستر اتيجية سوم على طلاب المجموعة الضـابطة اللذين درسوا

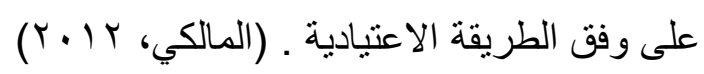

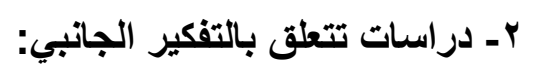

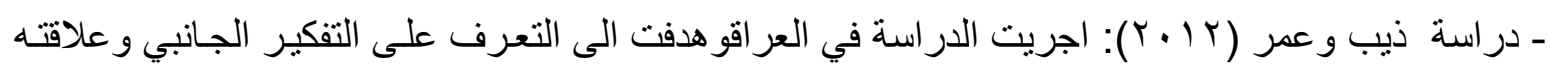
بسمات الثخصية على وقف انمـوذج قائمسة العوامل الخمكسة للثخصية لدى طلبـة الجامعـة ،اعد الباحثنان اختبار اللتفكير الجانبي وتبنيا مقياس قائمة العو امل الخمسـة للثخصـة من اعداد كوستا ، اسفرت النتائج عن انخفـاض مسـتوى التفكير الجـانبي للدى طلبـة الجامعـة بمختلف التخصصـات و الجنس ، وعد وجـود علاقـة احصائية بين التفكير الجانبي وسمات العصابة والانبساطية والطيبة ، في اثبتت نتائج البحث عن وجود علاقـة

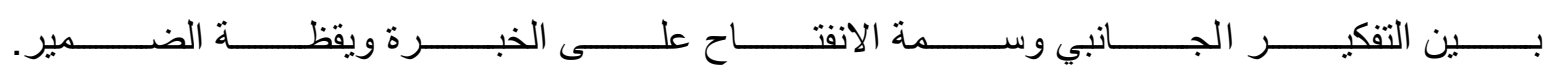

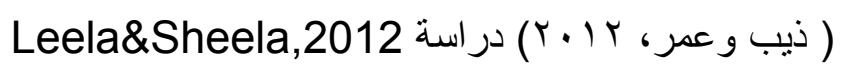

اجريت الدراسة في الهند وهدفت الى التعرف على اثر استخدام تقنيات التفكير الجانبي في تحصيل

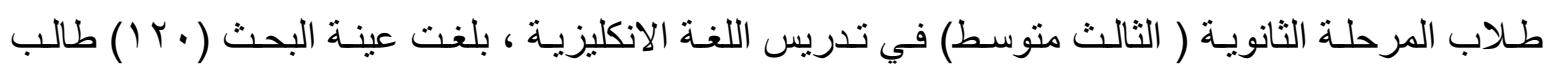
وزعوا على مجمو عتين تجريبية تدرس على وفق تقنيات التفكير الجانبي وضـابطة تدرس على وفق الطريقة الاعتيادية ، اسفرت النتائج عن تفوق طلاب المجموعة التجريبية على طلاب المجموعة الضـابطة في اختبار التحصيل البعدي. (Leela\&Sheela,2012)

\section{الفمل الثالث: منمبية البمث واجراكاته}

اولا: منهجية البحث: تعد منهجيـة البحث الطريقة التي يسلكها الباحث في الإجابة عن الأسئلة، وهي خطة

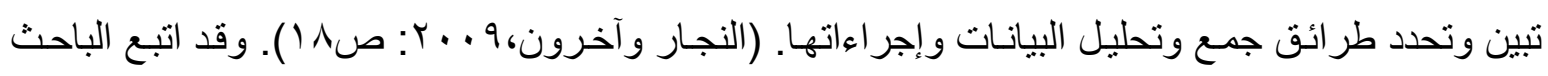
المنهج التجريبي في بحثِهِ لمناسبتهِ لطبيعتهِهِ وأهدافِه.

ثانيا: التصميم التجريبي: يقصد بالتصميم التجريبي التخطيط المسبق للظروف و العوامل المحيطة بالظـاهرة

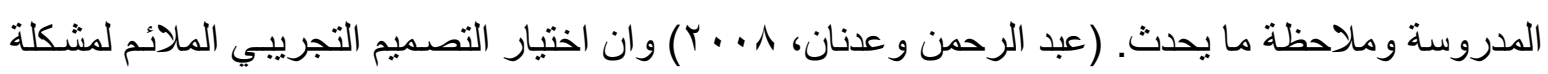
البحث أهمية كبيرة إذ يضمن الدقة العلمية والوصول الى نتائج موثوقة في الاجابـة عن الاسئلة التي تطرحها

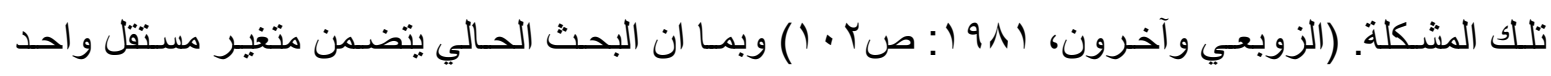
(ستر اتيجية سوم) و متغيرين تابعين (البنية الرياضية و التفكير الجانبي) ، لذا اعتمد الباحث التصميم التجريبي

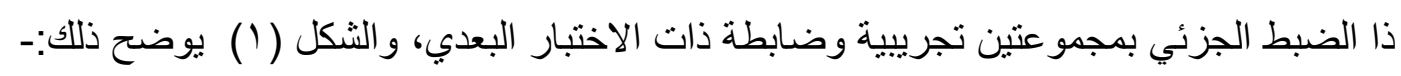

\begin{tabular}{|c|c|c|c|}
\hline المتغير التابع & المتغير المستقل & تكافؤ المجموعتين & المجموعة \\
\hline \multirow{2}{*}{ ـ التفكير الجانبي الرياضية } & ستر اتيجية سوم & \multirow{2}{*}{ ـ ـ ـ التفكير الجانبي الزمني } & التجريبية \\
\hline & الطريقة الاعتيادية & & الضابطة \\
\hline
\end{tabular}


ثالثا:- مجتمع البحث وعينته: يعد تحديد مجتمع البحث من الخطوات المنهجية المهمة في البحوث التربويـة و هي تتطلب دقة بالغة، إذ يتوقف عليها اجر اء البحث وتصميمه وكفاءة نتائجهـ. ويقصد بمجتمع البحث جميع

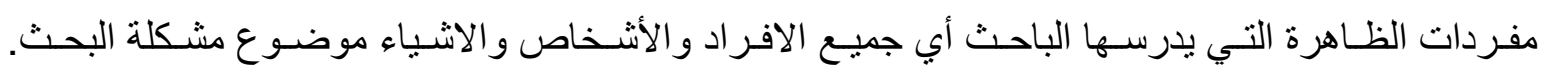

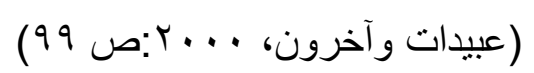

وقد نالف مجتمع البحث من جميع طلاب الصف الاول المتوسط في المدارس التابعة لمديريـة تربيـة

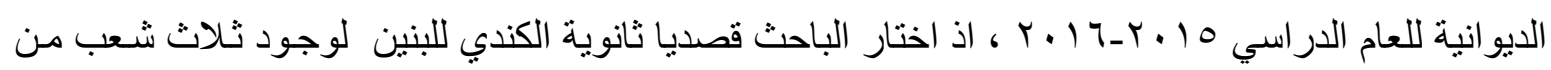
طلاب الصف الاول المتوسط اضافة الى ان ادارة المدرسة قد بينت ان توزيع الطلاب على الثـعب الثلاث قد تم بصورة عشو ائية. وتم عشوائيا اختيار الثعبة (أ) لتمثل المجموعة التجريبية والتي يبلغ عدد طلابها (بr)،

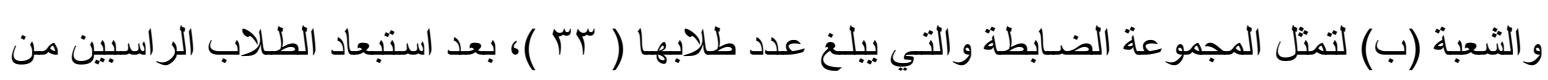
الثعبتين. و الجدول ( 1 ) يوضح ذلك.

جدول (1) عدد طلاب مجموعتي البحث قبل وبعد الاستبعاد

\begin{tabular}{|c|c|c|c|c|}
\hline عدد الطلاب بعد الاستبعاد & عدد الطلاب الراسبين & عدد الطلاب قبل الاستبعاد & الشعبة & المجموعة \\
\hline$r r$ & ir & $\leqslant 7$ & أ & التجريبية \\
\hline$r r$ & 9 & $\leqslant Y$ & ب & الضابطة \\
\hline 79 & rY & $1 \wedge$ & & المجموع \\
\hline
\end{tabular}

الزمني، التفكير الجانبي، درجات الرياضيات للسنة السابقة والذكاء ) ،وكما مبين في الجدول (r) . جدول ( r ) نتائج الاختبار التائي للمتغيرات الاربع لطلاب مجموعتي البحث

\begin{tabular}{|c|c|c|c|c|c|c|c|c|}
\hline \multirow{2}{*}{ 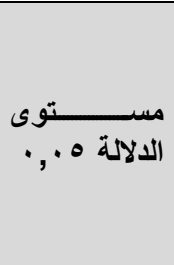 } & \multicolumn{2}{|c|}{ القيمة التائية } & \multirow{2}{*}{ درجية الحرية } & \multicolumn{2}{|c|}{ المجموعة الضابطة } & \multicolumn{2}{|c|}{ المجموعة التجريبية } & \multirow{2}{*}{ المجموعة } \\
\hline & الجدولية & المحسوبة & & 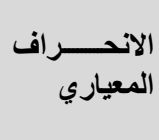 & الحستوسبـــــ المي & الانعيـــــــــ اف & الحستوسيــــ الحي & \\
\hline غير دالة & \multirow{4}{*}{ r } & $1 . r r$ & \multirow{4}{*}{$7 \varepsilon$} & $0 . V$ & $1 \leq V . \varepsilon$ & $\varepsilon .0$ & $1 \leqslant 7$ & العُمر الزمني \\
\hline غير دالة & & 1.07 & & 7.8 & rr.s & 0.7 & rY.00 & الجانبي \\
\hline غير دالة & & $1 . r r$ & & $0 . \leqslant r$ & $V 7.9$ & $7 . Y Y$ & $v 0.0$ & الرياضيات \\
\hline غير دالة & & 1.8 & & $0 . r$ & $\varepsilon q . \mu r$ & $\leqslant .00$ & $\varepsilon \wedge . \xi$ & الأكاء \\
\hline
\end{tabular}

خامسـا: تحديد المـادة العلميـة: حددت المـادة العلميـة التي ستدرس لمجموعتي البحث وقد تضـنت الفصل الاول و الفصل الثاني و الفصل الثالث من كتاب الرياضيات للصف الاول المتوسط للعـام الدراسي 10 ـ ؟ـ

سادسـا: صياغة الاهداف السـلوكية: ان كتابـة الاهداف السـلوكية لبست غايـة في حد ذاتها مسالم تكن هذه الاهداف جز ءا من عملية تحليل المحتوى وتعمل على اختيـار المحتوى وتصميم المـادة التعليمية ، واختيار 


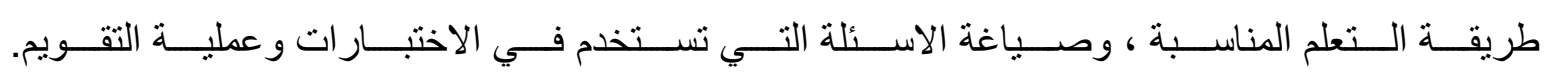

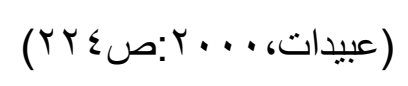

استعان الباحث في كتابـة الاهداف السلوكية لمستويات بلوم الثلاثة الاولى ( التذكر، الفهم، التطبيق)

بكتاب الطالب للفصول الثناثة الاولى من كتاب الرياضيات للصف الاول المنوسط للعام الدر اسي 10 ـ ؟-

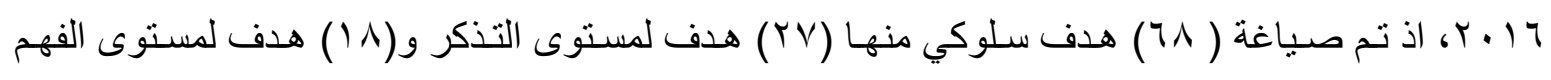

و(r (Y) هدف لمستوى التطبيق، للاعتماد عليها في اعداد الخطط التدريسية وبناء اختبار البنية الرياضية . سابعا: اعداد الخطط التدريسية: تم اعداد نو عين من الخطط التدريسية لمجموعني البحث، التجريبية التي تدرس على وفق ستر اتيجية سوم والضـابطة التي تدرس على وفق الطريقة الاعتيادية، وقد عرضت على لى مجمو عة من المحكمين من ذوي الاختصاص في طر ائق التدريس، ومدرسي الرياضيات لللإفادة من آرائهم

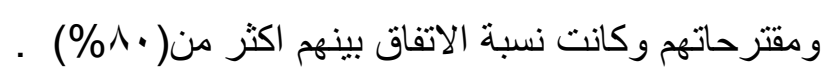

ثامنا: اداة البحث 1 ا اختبار البنية الرياضية: اعد الباحث اختبار البنية الرياضية بالاستعانة بجدول المواصفات ، اذ تم تحديد

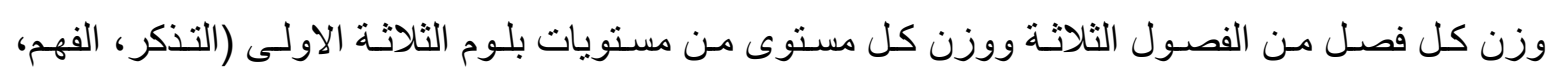

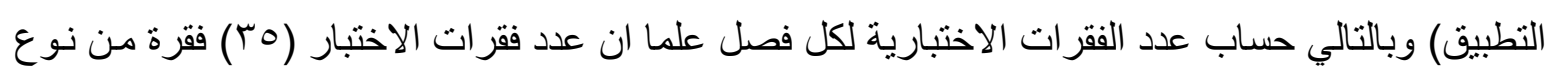
الاختيار من متعدد والذي يتكون من اربعة بدائل ، وتم اعداد نعليماته وتوضيح كيفية الاجابة من خلال مثال . صدق الاختبار: الصدق الظاهري: يعد الصدق الظاهري من المقومات الاساسية التي ينبغي ان تتوفر في أداة

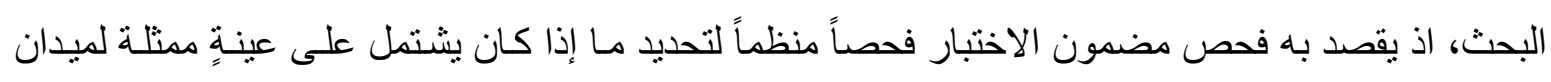

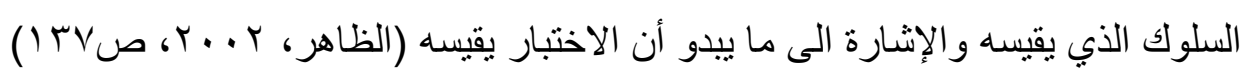
وقد تم التحقق من الصدق الظاهري للاختبار من خلال عرضه على مجموعـة من المحكمين والخبراء

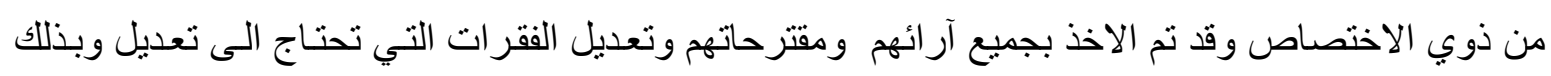

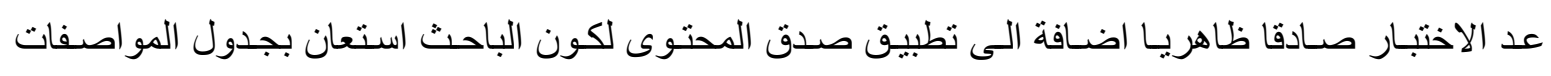

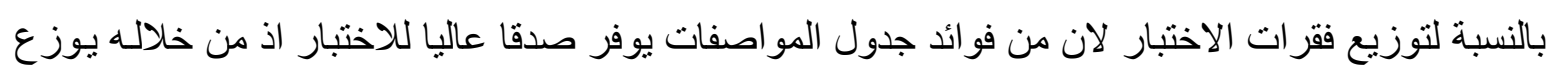

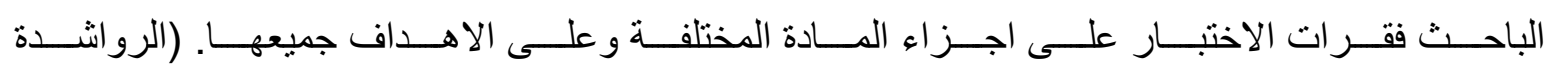

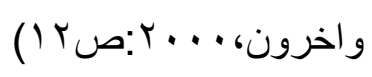

التحليل الاحصائي لفقرات الاختبار: طبق الاختبار على عينة استطلاعية في متوسطة الامـام علي (ع) للبنين بلغ عددها ( •V) طالب وتم تحديد وقت الاختبار فوجد انه يساوي (• (7) دقيقة. ثم رتبت درجاتهم بعد تصحيح

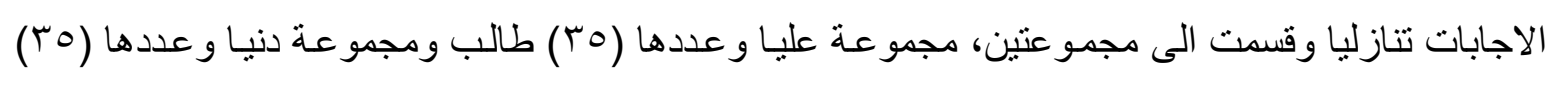
طالب اي بنسبة ( •0\%) لكل مجموعة، وقد تم حساب معامل الصعوبة لفقرات الاختبار فوجد انه يتر اوح بين

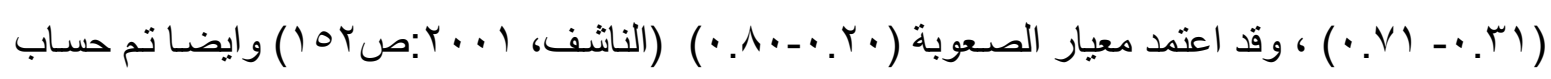

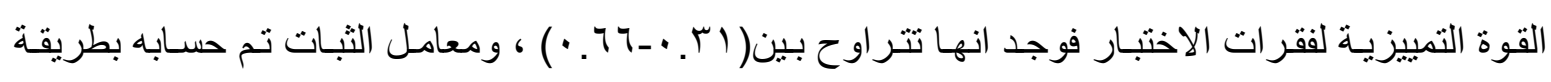

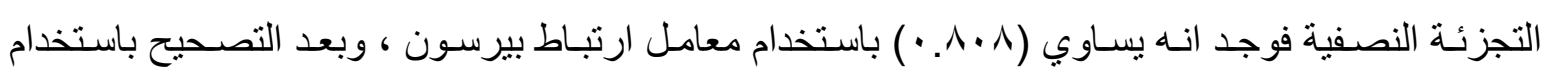




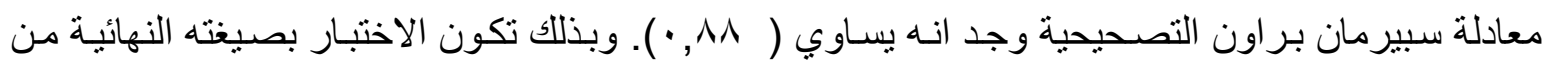
(0) فقرة اعطيت درجة واحدة للاجابة الصحيحة و (صفر) للاجابة الخاطئة.

r ـ اختبار التفكير الجانبي: لما كان التفكير الجانبي احد المتغير ات التابعة في البحث الحالي ، لذ فأنتا بحاجـة الى اختبار قياس التفكير الجانبي ولم يجد الباحث اختبار جاهز لاستخدامه في البحث لذان تم اعداد اختبار من

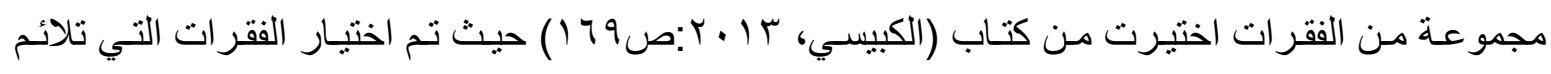

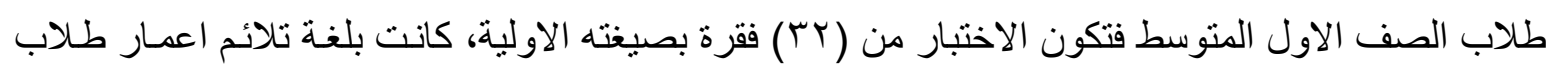
الصف الاول المتوسط، وقد تم اعداد تعليمات الاختبار وكيفية الاجابة عليها . صدق الاختبار أـ الصدق الظاهري: من اجل التحقق من صدق الاختبار الظاهري عرض الباحث فقرات الاختبار بصيغته الاولية غلى مجموعـة من المحكمين من ذوي الاختصـاص وقد جاءت نتيجة ار ائهم حول فقرات الاختبار بنسبة اتفاق اكثر من ه^\% وبذلك تعد فقر ات الاختبار صادقة . بـ صدق البنـاء: للتحقق من صدق البناء من خـلال ارتباط درجـة كل فقرة من فقرات الاختبـار بالدرجـة

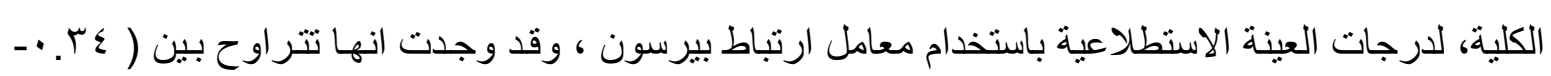

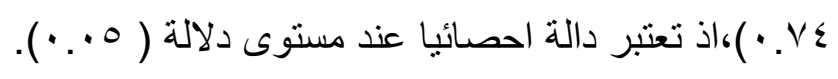
التحليل الاحصسائي لفقرات الاختبـار: طبق الاختبار على عينـة استطلاعية تكونت من ( . . 1) طالب وبعد تصحيح الاجابات رتبت نتازليا وتم تقسيم الدرجات الى مجموعتين ، مجموعة عليا تكونت من ( • (0) درجـة ، ومجمو عة دنيا تكونت من ( •0) درجة ، وتم حساب معامل الصعوبة لفقرات الاختبار فوجد انها تتر اوح بين

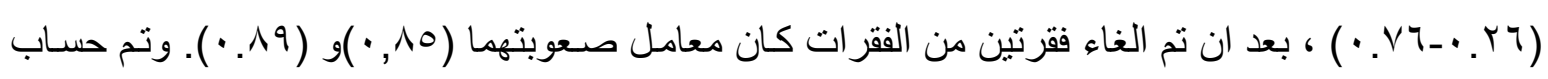

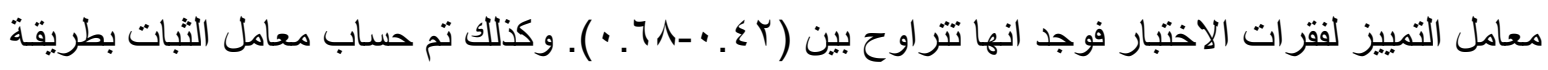

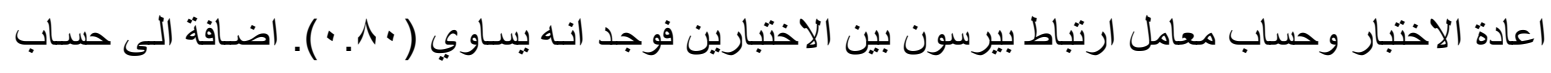
الوقت اللازم للاختبـار فوجد ان ( •0) دقيقة كافيـة لأداء الاختبـار . وبـللك اصبح الاختبـار بصيغته النهائيـة مكون من ( •r) فقرة اعطيت ( ( ) درجة للإجابة الصحيحة و(صفر) للإجابة الخاطئة.

\section{الفصل الرابع: نتائج البمث وتفسيرها}

اولا: نتـائج البحث: الفرضية الاولى (لا يوجد فرق ذو دلالـة إحصـائية عند مستوى الدلالـة (0. . •) بين متوسط درجات طلاب المجموعة التجريبية التي درست على وفق إستر اتيجية سوم ومتوسط درجات طلاب المجمو عة الضابطة التي درست على وفق الطريقة التقليدية في اختبار البنية الرياضية) ـ وللتحقق من دلالية الفرق بين المجموعتين التجريبيـة والضـابطة في اختبـار البنيية الرياضية تم استخدام الاختبار التائي بين درجات المجمو عتين وكما مبين في الجدول ( r ) ادناه:- 
جدول ( r ) ) نتائج الاختبار التائي لمجموعتي البحث في اختبار البنية الرياضية

\begin{tabular}{|c|c|c|c|c|c|c|c|}
\hline الدلالة & الجدئلية التـائيـــة & المحسوبـة التـائبـــــة & الحرية لدرجة & التباين & الحستوسبــ المبي & العدد & المجموعة \\
\hline \multirow[b]{2}{*}{ دالة } & \multirow[b]{2}{*}{ r } & \multirow[b]{2}{*}{$r . \leqslant \Lambda}$. & \multirow{2}{*}{$7 \varepsilon$} & 7.21 & $r \wedge . \leqslant 0$ & $r r$ & التجريبية \\
\hline & & & & $V .1 T$ & $r$ r. & س & الضابطة \\
\hline
\end{tabular}

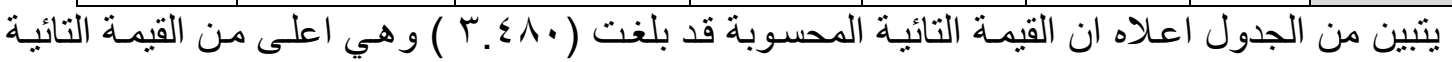

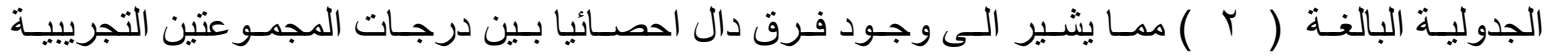
و الضابطة في اختبار البنية الرياضية وبذلك ترفض الفرضية الصفرية .

الفرضية الثانية (لا يوجد فرق ذو دلالة إحصـائية عند مستوى الدلالة (0 . . • ) بين متوسط درجات طـلاب المجموعـة التجريبيـة التـي درسـت على وفق سـتر اتيجية سـوم ومتوسط درجـات طـلاب المجموعـة الضابطة التي درست على وفق الطريقة التقليدية في اختبار التفكير الجانبي). . وللتحقق من دلالة الفرق بين المجمـوعتين التجرييـة والضـابطة في اختبـار التفكيـر الجـانبي تـم اسـتخدام الاختبـار التـائي بـين درجـات المجمو عتين وكما مبين في الجدول (ع ) ادناه:-

جدول (؛ ) نتائج الاختبار التائي لمجموعتي البحث في اختبار التفكير الجانبي

\begin{tabular}{|c|c|c|c|c|c|c|c|}
\hline الدلالة & الجدئية القـة التائيــــة & المحسوبـة القيمة التائيــــة & الحرية & التباين & الحستوسيـــ المتي & العدد & المجموعة \\
\hline \multirow{2}{*}{ دالة } & \multirow{2}{*}{$r$} & \multirow{2}{*}{$0 . r .7$} & \multirow{2}{*}{$7 \varepsilon$} & $\varepsilon . Y Y$ & $Y \checkmark . \wedge \varepsilon$ & r & التجريبية \\
\hline & & & & $\varepsilon . \wedge V$ & $r \cdot .91$ & $r r$ & الضابطة \\
\hline
\end{tabular}

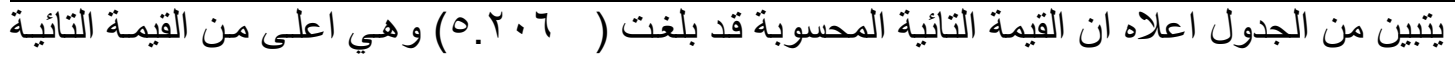
الجدولية البالغة (r) مما يثير الى وجود فرق دال احصـائيا بين درجات المجمو عتين التجرييية والضـابطة في اختبار التفكير الجانبي وبذلك ترفض الفرضية الصفرية . ثانيا: تفسير النتائج

البنيـة الرياضية: اسفرت النتائج عن تفوق المجموعـة التجريبية على المجوعـة الضـابطة في اختبار البنيـة الرياضية وقد ارجع الباحث هذا التفوق الى ان ستر اتيجية سوم هي احدى الستر اتيجيات الحديثة التي اسهمت في تعليم الطلاب وتمكنهم من المادة العلمية من خلال التنوع في المهار ات و الانشطة التعليمية مما ولد الرغبـة في دراسة المادة اضافة الى ان هذه الستر اتيجية بما تقوم عليه من مهار ات يعد اسلوب فاعل في زيادة التفاعل بين الطلاب من جهة و المادة العلمية من جهة اخرى وساعدت على زيادة ثقة الطلاب بأنفهر وتقصي الحقائق الو اردة في الموضوع وايضا زادت من ثركيز الطلاب من خلال فتح باب المناقتشة فيما بينهم ممـا سـاعد على تعدد الافكار المطروحسة وكذلك جعلت من الطالب محور اللعملية التعليميـة من خلال مشـاركة الطلاب مـع المدرس و عدم تسيد الموقف التعليمي من قبله و هذا يتفق مع مـا تتادي بـه ادبيـات التعليم من جعل المتعلم محور اللعمليـة التعليميـة اضـافة الى ان التدريس على وفق هذه الستر اتيجية قد ادى الى تتظيم الافكـار الرياضية بشكل متسلسل منطقيا وبالتالي سهولة استرجاعها. 
التفكير الجـاتبي: اظهرت النتائج تفوق المجموعـة التجريبيـة التي درست على وفق ستر اتيجية سوم على المجموعة الضابطة التي درست على وفق الطريقة الاعتباديـة في اختبار التفكير الجانبي وقد ارجع الباحث هذا التفوق الى ان ستر اتيجية سوم بما تتضمنه من مهار ات تعد اسلوب جيد لتنمية التفكير بوجهه عام و التفكير

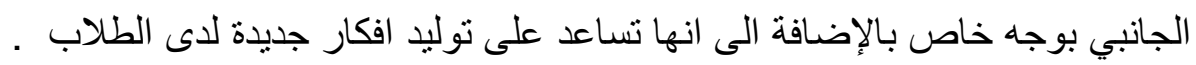
الاستنتاجات

ا - ستر اتيجية سوم تزيد من تمكن طلاب الصف الاول المنوسط من البنية الرياضية .

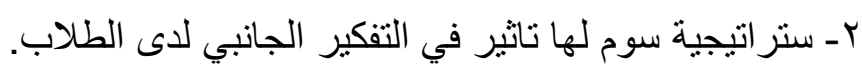

التوصيات

1ـ التدريس على وفق ستر اتيجية سوم لما لها من تاثير في تمكن الطلاب من المادة العلمية في الرياضيات. r- تدريب الملاكات التدريسية على استخدام هذه الستر اتيجية في تدريس مادة الرياضيات. rـ تدريب الطلبة في المرحلة الجامعية على مهارات وستراتيجيات التفكير الجانبي. المقترحات ا ـ اجر اء در اسة مماثلة باستخدام ستر اتيجية سوم وتاثير ها في متغيرات اخرى . r- اجر اء در اسة باستخدام سنر اتيجية سوم لمر احل دراسية اخرى. ب- در اسة تاثير ستر اتيجية مقترحة في التفكير الجانبي. ع - در اسة التفكير الجانبي ومتغير ات اخرى مثل انو اع اخرى من التفكير. 0ـ اجر اء دراسة تاثير برامج تدريبية معينة في التفكير الجانبي.

المصادر

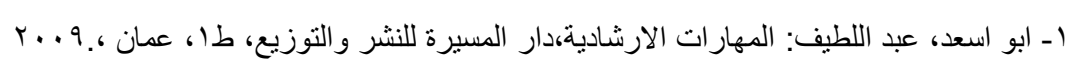

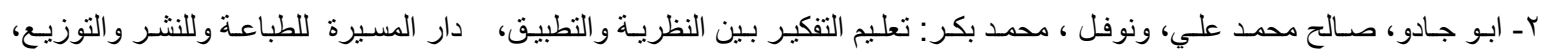

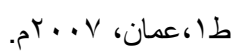

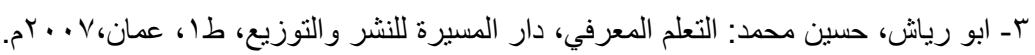

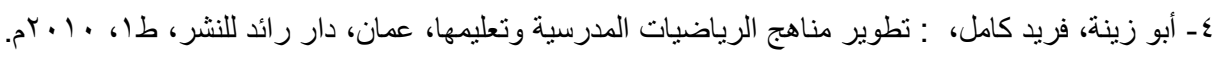

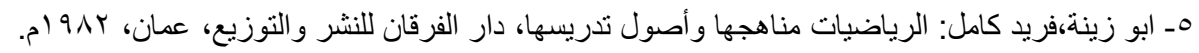

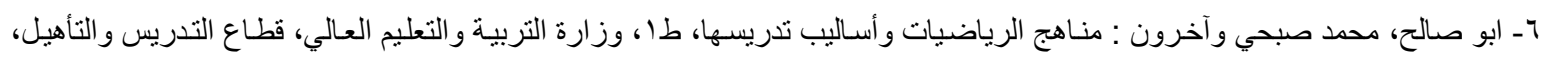

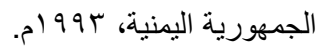

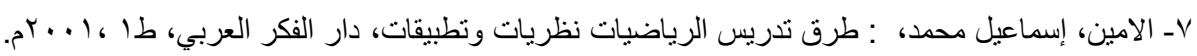

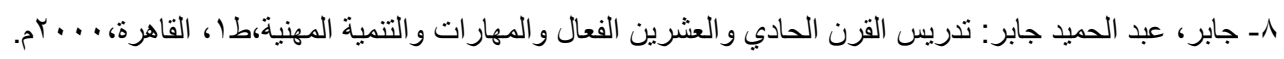

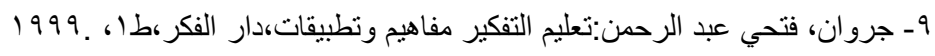

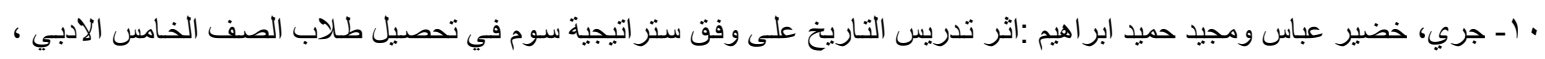

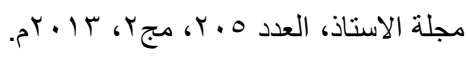

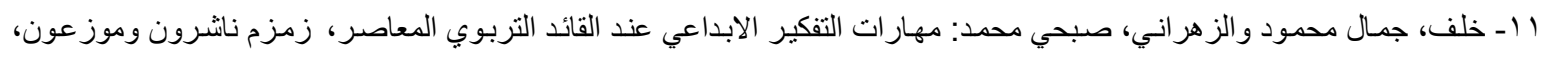

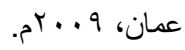

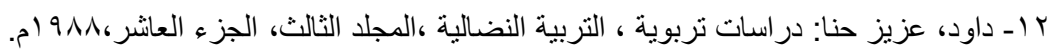

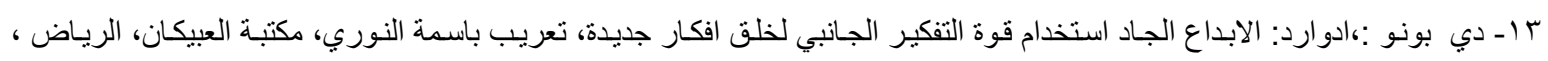




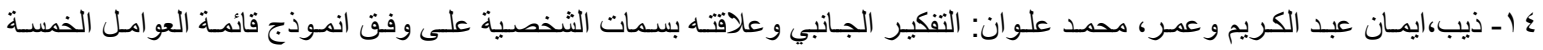

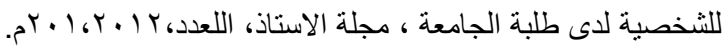
1 1 ـ الرو اثدة ،ابر اهيم واخرون: مرشد العلم في الاختبار ات التحصيلية ، مطابع وزارة التربية والتعليم، الاردن ، . . . rم.

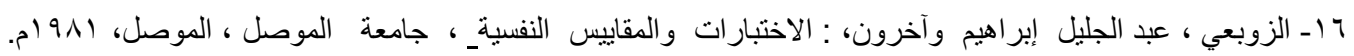

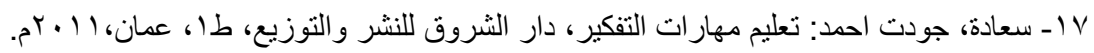

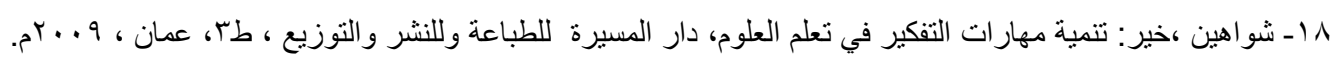

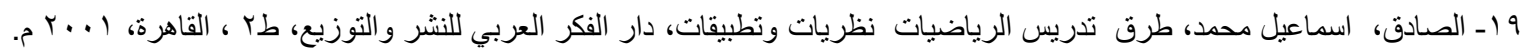
• ץ- عبد الرحمن، أنور حسين و عدنان حقي زنكنة، : الأسس التصورية والنظرية في مناهج العلوم الإنسانية والتطبيقية ، الكتاب الأول ، طال

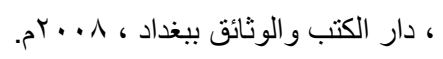

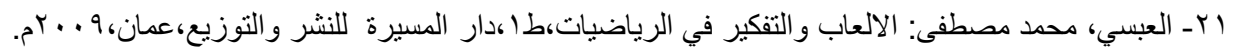

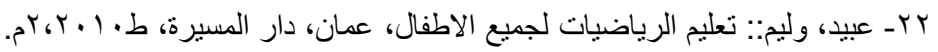

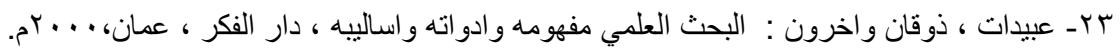

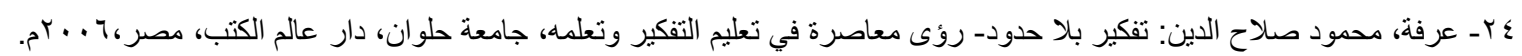

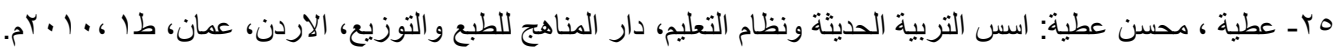

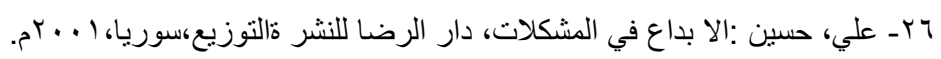

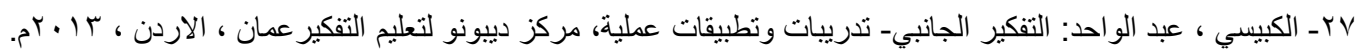

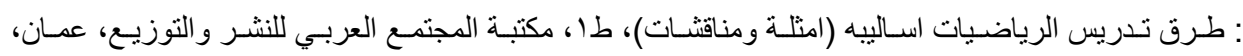
$-r \Lambda$ A . T و بـ الكبيسي، و هيب مجيد: الاسلوب المعرفي ( التصلب والمرونة) وعلاقته بحل المشكلات ،اطروحة دكتور اه غير منشورة، جامعة بغداد، كلية التربية ،919 إم. • بــ الكتبي، سليم حسن: "السمات الفكرية للرياضيات المعاصرة"، مجلة علوم المستنصرية، المجلدو، العدد ا، مطبعة كلية العلوم في جامعة المستنصرية، بغداد، 991 ام. ل

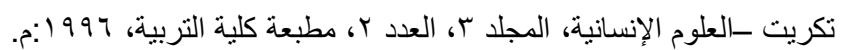

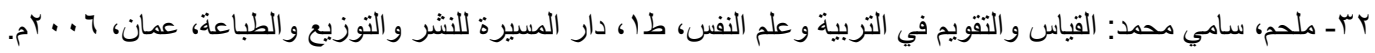

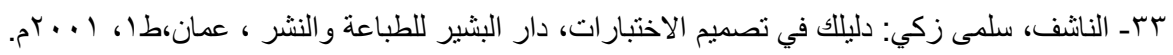

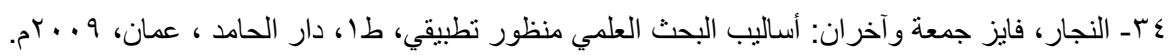

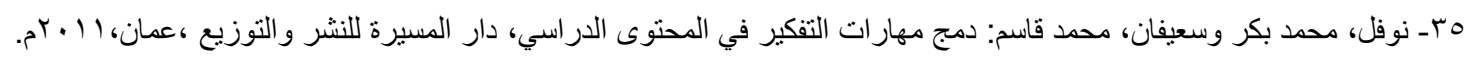

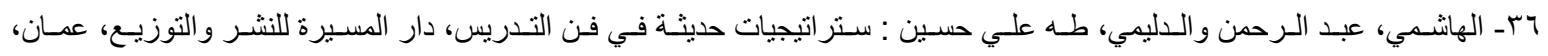

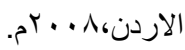

37- Goet Z.E al: Educational psychology, Newyorkmacmatalln ublishing co,1992.

38- Dienes Z. in aichele \& Reys (eds): (1977) Readings in secondary school Mathematics, prindle. Weber \& Schmidt. Inc, 1977.

- $\quad 39-$ Leela,K.S\&Sheela G.,: Effect of teaching English lateral thinking techniques on a achievement in English among secondary school students, Asian journal of development matters year,2012, volum,6,issu,2012. 